\title{
Genetic Diversity Characterization of Pleurotus strains by Random Amplified Polymorphic DNA Fingerprinting
}

\author{
M.K. Yadav ${ }^{1}$, Ram Chandra ${ }^{2}$, H.B. Singh ${ }^{2}$, S.K. Yadav ${ }^{4}$, S.K. Yadav ${ }^{3}$, \\ Sushreeta Naik $^{2}$ and P.K. Dhakad ${ }^{2}$ \\ ${ }^{1}$ Rani Lakshmi Bai Central Agricultural University, Jhansi-284003 (U.P.), India \\ ${ }^{2}$ Department of Mycology and Plant Pathology, ${ }^{3}$ Department of Agricultural Entomology and \\ Zoology, ${ }^{4}$ Department of Botany, Institute of Agricultural Sciences, Banaras Hindu University, \\ Varanasi-221005 (U.P.), India \\ *Corresponding author
}

\section{A B S T R A C T}

\begin{tabular}{|c|}
\hline Keywords \\
\hline $\begin{array}{l}\text { Clusters, } \\
\text { Dendrogram, } \\
\text { Genetic diversity, } \\
\text { Molecular marker } \\
\text { Pleurotus. }\end{array}$ \\
\hline Article Info \\
\hline $\begin{array}{l}\text { Accepted: } \\
\text { 12 April } 2017 \\
\text { Available Online: } \\
10 \text { May } 2017\end{array}$ \\
\hline
\end{tabular}

Keywords

Clusters,

Dendrogram

arker,

10 May 2017

\section{Introduction}

The use of wild mushrooms for food in all probability began with the prehistoric man. During the long period human as a hunter gathered the fungi of the forest that has served as an important source of nourishment. There are many edible mushrooms i.e. Volvarias, Polypores and tubers fungi that used ethnobotanical food by the tribal of forest regions. These are obviously non toxic as these have been in intimate human consumption by native and tribal, since antiquity (Pandey and Srivastava, 1994). However, the food value and acceptance of these edible fungi by the scientific and civilized world have not been recognized. These fungi are more important for a tropical/ subtropical country like India, which has a climate most congenial for the natural growth of such fungi (Purkayastha and Chandra, 1985). Describing the number of fungi on earth has been a position of conversation and several studies have focused on enumerating the world's fungal diversity (Crous et al., 2006). Only a part of total fungal wealth has been subjected to scientific 
study and mycologists continue to disentangle the unknown and hidden wealth one third of fungal diversity of the globe exists in India and of this only $50 \%$ are characterized until now (Manoharachary et al., 2005). Mushrooms have been extensively studied in the Western countries, while tropical countries like India especially in Vindhya forest of Northern India. However no determined efforts have been made for a detailed study of them. Till today no research have been done on natural mushroom flora, further attempt on isolation, characterization and maintenance of cell mycelial culture both in vitro and ex vitro yet to carry out. Mean while in Vindhya region several mushrooms have been reported and described on morphological basis by the various workers (Rahi, 2001).

The main objectives was to typical diversity of fleshy fungi, characterize, collect preserve and evaluate edibility of these different species in dry deciduous forest of Vindhya region of Northern India. RAPD fingerprinting has been used for genetic diversity analysis, varietal identification and strain protection in various field crops. RAPD markers have also been successfully used to detect genetic variation in a wide variety of fungal species including mushrooms.

\section{Materials and Methods}

\section{Random amplified polymorphic DNA (RAPD) molecular marker}

Some of the collected different strains of edible mushroom were characterized by RAPD analysis by the modified method (Yadav et al., 2003). Random amplified polymorphic DNA (RAPD) markers were used for evaluation of genetic diversity in selected group of Pleurotuss trains. Six RAPD primers used and all the strains were distinguished using aggregated RAPD data.
This study indicates that RAPD analysis is a sensitive and powerful tool for assessment of genetic variation at DNA level among Pleurotus strains.

\section{DNA isolation and purification}

Genomic DNA from fruit body was isolated by CTAB modified method (Dellaporta et al., 1983).

\section{DNA extraction solutions}

Isolation buffer $\quad 20 \mathrm{ml}$

$2 \%$ w/v CTAB (Cetyl Tri-methyl Ammonium

$\begin{array}{ll}\text { Bromide) } & 0.30 \mathrm{ml} \\ 1.4 \mathrm{M} \mathrm{NaCl} & 1.638 \mathrm{~g} \\ 20 \mathrm{mM} \text { EDTA (pH 8.0) } & 0.148 \mathrm{~g} \\ 100 \mathrm{mMTrisHCl}(\mathrm{pH} \mathrm{8.0)} & 0.315 \mathrm{~g}\end{array}$

Note

$0.2 \%$ mercaptoethanol was added immediately before use.

Phenol : Chloroform: iso-amyl alcohol (PCI)-25:24:1

Chloroform : iso-amyl alcohol (CI)24:1

$100 \%$ iso-propanol $: 0.30 \mathrm{ml}$

Washing solution : $70 \%$ ethanol, $10 \mathrm{mM}$ ammonium acetate

TE buffer

$\begin{array}{ll}10 \mathrm{mM} \text { TrisHCl } & 0.029 \mathrm{~g} \\ 1 \mathrm{mM} \text { EDTA }(\mathrm{pH} 8.0) & 0.037 \mathrm{~g}\end{array}$

$3 \mathrm{M}$ ammonium acetate $\quad 2.312 \mathrm{~g}$

\section{DNA isolation protocol}

$100 \mathrm{mg}$ fruit body of mushroom were quick freeze in liquid nitrogen $\left(-196^{\circ} \mathrm{C}\right)$ and grind to a fine powder in pre-chilled autoclaved 
mortar and pestle. Powder was transferred to a sterile $2 \mathrm{ml}$ centrifuge tube. Thawing was carefully avoided and $1000 \mu \mathrm{l}$ of extraction buffer was added and mixed thoroughly. The centrifuge tubes were incubated for 30 minutes at $60^{\circ} \mathrm{C}$ in water bath with intermittent swirling at every 10 minutes. One volume of phenol: chloroform: iso-amyl alcohol (25:24:1) was added into the tubes, capped and extracted for 10 minutes on a rotary shaker. Mixing was done gently but thoroughly to ensure emulsification. The tubes were centrifuged at $10 \mathrm{~K} \mathrm{rpm}$ for 10 minutes. Depending upon the purity of DNA preparation; the upper aqueous phase was extracted 2-3 times with fresh chloroform: iso-amyl alcohol (24:1). The final aqueous phase was transferred to other centrifuge tubes. To these, 0.6 volume of ice cold isopropanol was added and mixed gently by inverting the tube. At this stage, DNA-CTAB complex was found to precipitate as a whitish matrix. The pellet was gently agitated for few minutes and collected by centrifugation at $4^{\circ} \mathrm{C}$ ). Residual CTAB buffer was removed in this step. The tubes were inversed and drained on a paper towel for $1 \mathrm{hr}$ with care so that the pellet does not slip down. Pellet was neither containing ethanol nor was too dry. An appropriate $(50 \mu \mathrm{l})$ volume of TE buffer was used to dissolve the pellet.

\section{Purification of DNA}

To remove the RNA, RNase A @ $10 \mu \mathrm{g} / \mathrm{ml}$ was added into the DNA solution and incubated at $37^{\circ} \mathrm{C}$ for 30 minutes. Equal volume of phenol: chloroform: iso-amyl alcohol (25:24:1) was added into it and centrifuged at $10000 \mathrm{rpm}$ for10 minutes. Aqueous phase was taken and equal volume of chloroform: iso-amyl alcohol (24:1) was added and centrifuged at $10000 \mathrm{rpm}$ for 10 min. To the aqueous phase, $1 / 20^{\text {th }}$ volume of $\mathrm{Na}$ acetate (3M, pH-5.2) and 2.5 volume of ethanol was added and incubated at $-20^{\circ} \mathrm{C}$ for
$1 \mathrm{~h}\left(\right.$ or $-70^{\circ} \mathrm{C}$ for $\left.30 \mathrm{~min}\right)$. Then the solution was centrifuged at $10000 \mathrm{rpm}$ for $10 \mathrm{~min}$, pellets were washed with $70 \%$ ethanol (10000 $\mathrm{rpm}, 5 \mathrm{~min}$ ), air dried and dissolved in distilled water. Yield of DNA was estimated using DNA markers by electrophoresis.

\section{PCR amplification}

PCR amplification was performed by Williams et al., (1990). PCR amplification was carried out in $0.2 \mathrm{ml}$ thin-wall PCR tubes using an Eppendorf (model AG 22331 Hamburg) thermal cycler. A total of 6 RAPD primers were screened in our present study (6 primers from kit $S$ ) was amplified. 6 primers (viz. S43, S1017, S159, S485, S75 and S24) could produce unambiguous polymorphic bands and was selected for the present study. The preparation of Polymerase chain reaction (PCR) mixture of $25 \mu \mathrm{l}$ was in table 1. PCR cycle conditions were as follows: initial denaturing step at $94^{\circ} \mathrm{C}$ for $3 \mathrm{~min}$ followed by 44 cycles of $94^{\circ}$ for $1 \mathrm{~min}, 37^{\circ} \mathrm{C}$ for $1 \mathrm{~min}$ and $72^{\circ} \mathrm{C}$ for $2 \mathrm{~min}$. In the last cycle, primer extension at $72^{\circ} \mathrm{C}$ for 7 min was provided.

\section{Gel electrophoresis and documentation}

PCR products were electrophoretically separated on a 1.2\% Agarose gel containing Ethidium Bromide using 1X TAE buffer $(\mathrm{pH}$ 8.0). Agrose gel $0.480 \mathrm{~g}$ was dissolved in $40 \mathrm{ml}$ of $1 \mathrm{X}$ TAE buffer and boiled. After that add $2 \mu \mathrm{l}$ of EDTA dye mixed and poured in plate of gel. After that solidify the gel were kept in gel electrophoresis instruments; load the samples and Ladder and switch on the electric charge for running gel electrophoresis.

The amplified products were visualized and photographed under UV light source. As molecular marker, 100 bp DNA Ladder Plus (ready-to-use) (Fermentas Inc.) was used. The ranges of fragments were measured in this 
particular molecular weight marker varied from $3000 \mathrm{bp}$ to $100 \mathrm{bp}$.

\section{RAPD data analysis}

DNA bands were scored ' 1 ' for its presence and ' 0 ' for its absence for each primergenotype combination. Only unambiguous bands were scored for identifying presence and absence of bands. A similarity matrix was constructed, using Jaccard's coefficient, and the resulting similarity data were used to construct a dendrogram, using UPGMA and the NTSYS-pc software version 2.1 developed by Rohlf (1997).

\section{Results and Discussion}

Genetic diversity among the collected edible mushrooms (Pleurotus sp.) analysis by Random Amplified Polymorphic DNA

Genetic diversity of collected edible mushroom of eight species of Pleurotus is revealed by Random Amplified Polymorphic DNA (RAPD). DNA bands were scored ' 1 ' for its presence and ' 0 ' for its absence for each primer-genotype combination (Fig. 1). Only unambiguous bands were scored for identifying presence and absence of bands. A similarity matrix was constructed, using Jaccard's coefficient, and the resulting similarity data were used to construct a dendrogram, using UPGMA and the NTSYSpc software version 2.1 developed by Rohlf (1997).

A total 8 Pleurotus sp. were tested for their genetic variability by RAPD analysis, using 6 random primers. These primers viz. S43, S1017, S159, S485, S75 and S24 produced easily scorable and consistent banding patterns, which were used for RAPD analysis of test. The amplified products were ranged from $200 \mathrm{bp}$ to $1250 \mathrm{bp}$. Analysis of the genetic coefficient, derived from the scores of RAPD profile, showed that minimum and maximum \% diversities among the Pleurotus $s p$. were ranged from 30 to $70 \%$, respectively (Fig. 2). Cluster analysis, using Unweighted Pair-Group Method with Arithmetic Mean (UPGMA), clearly separate dendrogram was obtained from the molecular marker systems for all the 8 Pleurotus sp. Clustering on the basis of RAPD marker using Jaccard's coefficient generated two (I and II) broad groups of six and two Pleurotus sp. Clusters also confirmed $70 \%$ of genetic diversity among the Pleurotus sp. (Fig. 2). Cluster I consisted 6 (PL-1, PL-2, PL-3, Psc-1, Psc-2 and PF-1) and cluster II consisted 2 (PO-1 and PE-1) Pleurotus species. Cluster I were further separated in to two sub cluster (A and B) with $67.5 \%$ diversity.

Table.1 Detail of polymerase chain reaction (PCR) mixture of $25 \mu 1$

\begin{tabular}{|c|c|c|}
\hline S. No. & Component & Quantity \\
\hline $\mathbf{1}$ & Sterile Milli Q water & $19.05 \mu \mathrm{l}$ \\
\hline $\mathbf{2}$ & $10 \times$ Taq buffer & $2.5 \mu \mathrm{l}$ \\
\hline $\mathbf{3}$ & d NTPs & $0.25 \mu \mathrm{l}$ \\
\hline $\mathbf{4}$ & Random primer & $1.0 \mu \mathrm{l}$ \\
\hline $\mathbf{5}$ & Taq DNA polymerase & $0.2 \mu \mathrm{l}$ \\
\hline $\mathbf{6}$ & Template DNA & $2.0 \mu \mathrm{l}$ \\
\hline
\end{tabular}


Fig.1 Genetic diversity of eight Pleurotus sp. Analysis by Random Amplified Polymorphic DNA by Gel Electrophoresis

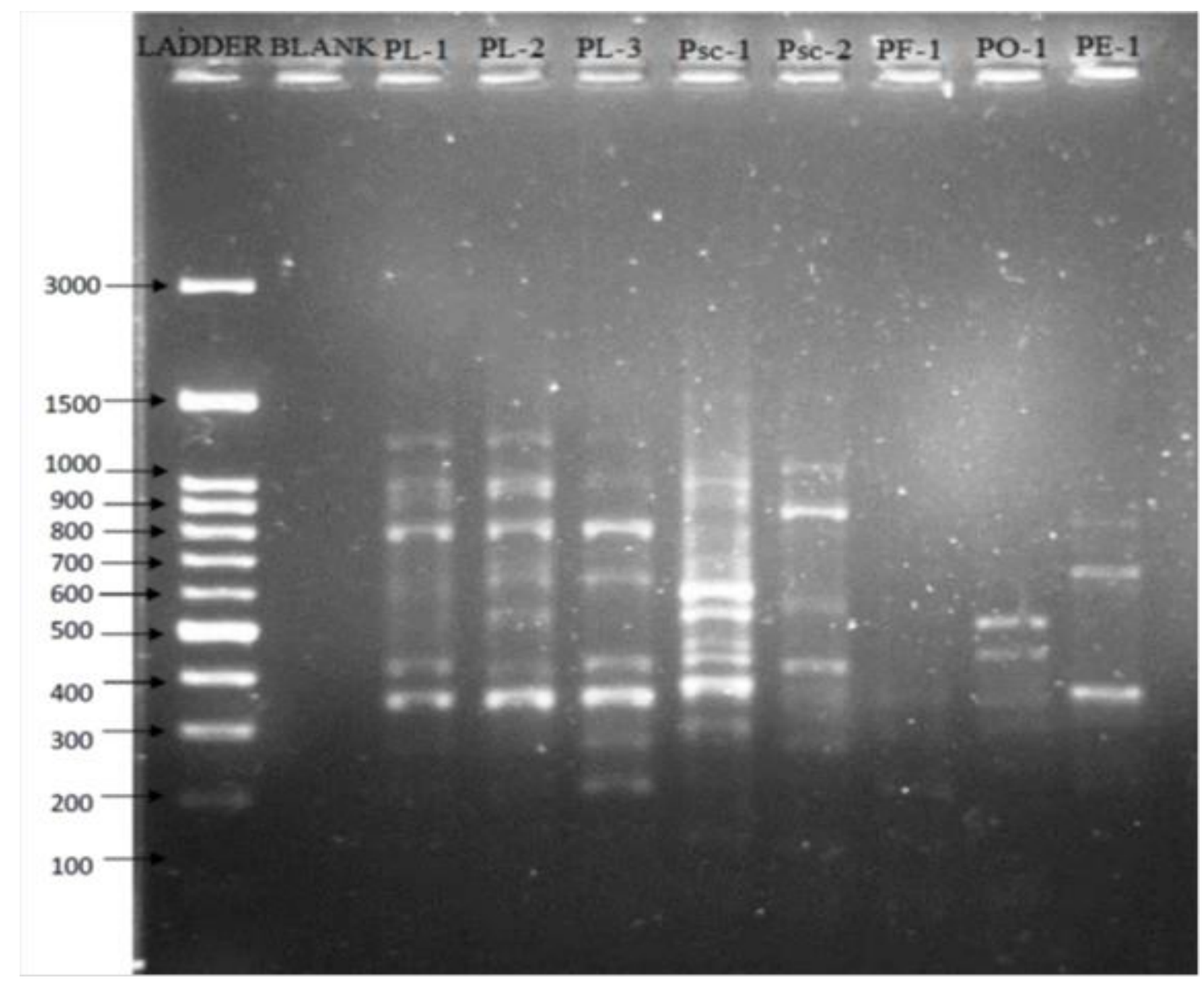


Fig.2 Dendrogram of eight Pleurotus sp. analysis of genetic dissimilarities based on random amplified polymorphic DNA data with 6 primers

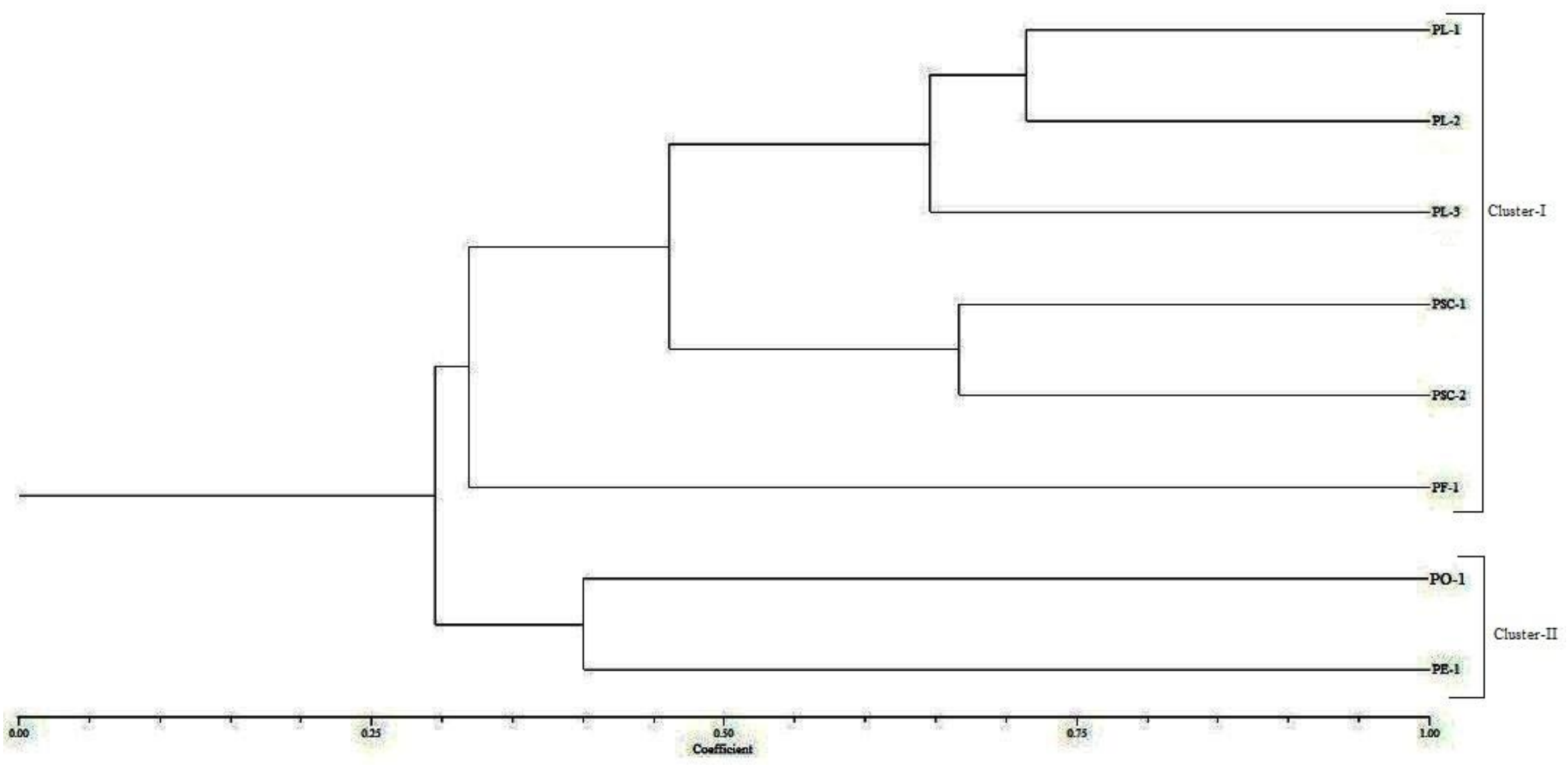


The sub cluster A was also divided into two groups $\mathrm{Aa}$ and $\mathrm{Ab}$ with $58.5 \%$ diversity. Aa group consisted two Pleurotus sp. (Psc-1 and Psc-2) having $35 \%$ variability while sub cluster $\mathrm{Ab}$ divided into two having $37.5 \%$ variability; one cluster consisted only one Pleurotus sp.(PL-3) and another consisted two Pleurotus sp. (PL-1 and PL-2) with having $30 \%$ variability. The sub cluster $\mathrm{B}$ was consisted one species PF-1.

The result is confirmative with finding of Yin et al., (2013) who investigated that the molecular markers were used to analyze the genetic diversity of 15 Chinese $P$. pulmonarius cultivars. In total, 21 RAPD primers selected for generating data based on their clear banding profiles produced. With the use of these RAPD primers, a total of 361 RAPD fragments were detected, of which 287 (79.5\%) RAPD fragments were polymorphic. UPGMA trees of these three methods were structured similarly, grouping the 15 tested strains into four clades. Subsequently, visual DNA fingerprinting and cluster analysis were performed to evaluate the resolving power of the combined RAPD markers in the differentiation among these strains.

The confirming result of Theochari et al., (2002) who studies an approach of the biodiversity was achieved by analyzing allelic polymorphism at mating type loci in a sample of $P$. ostreatus isolates, which made evident the variability likely to exist in this biological material.

In conclusion, the genetic diversity of Pleurotus species was ranged from 30 to $70 \%$. Cluster analysis, using UPGMA, clearly separate dendrogram was obtained from the molecular marker systems for all the 8 Pleurotus species. Clustering on the basis of RAPD marker using Jaccard's coefficient generated two (I and II) broad groups of six and two Pleurotus species. Clusters also confirmed $70 \%$ of genetic diversity among the Pleurotus species.

\section{References}

Crous, P.W. 2006. How many species of Fungi are there in tip of Africa? Studies in Mycol., 55: 13.

Dellaporta, S.L., Wood, J. and Hichs, J.B. 1983. Plant Mole. Boil. Repor., 1: 1921.

Manoharachary, C., Sridhar, K., Singh, R., Adholeya, A., Suryanarayanan, T.S., Rawat, S. and Johri, B.N. 2005. Fungal biodiversity: Distribution, conservation and prospecting of fungi from India. Curr. Sci., 89(1): 58-71.

Pandey, V.N. and Srivastava, A.K. 1994. Fleshy fungi go ethno-botanical food use in North Eastern Tarai region of Uttar Pradesh. Proceeding of the National Symposium on Mushroom, NRCM-Solan, 3.

Purkayastha, R.P. and Candra, A. 1985. Mannual of Indian Edible Mushroom, Today and Tomorrow Printer and Publisher, New Delhi, 266.

Rahi, D.K. 2001. Studies on the edible tribal mushrooms of M. P. and development of technology for large scale production. Ph. D. Thesis, R.D. University, Jabalpur (MP), India.

Rohlf, F.J. 1997. NTSYS-PC Numerical Taxonomy and Multivariate Analysis System Version 2.1, Exeter Software. Appl. Biostatistics, New York.

Theochari, I., Nikolaou, A. and Poulou, A. 2002. Resources of Pleurotus ostreatus and $P$. eryngii in Greece perspectives for cultivation and mushroom production. ActaHorticulturae, 579: 5963.

Yadav, M.C., Mahfooz, S., Singh, S.K. and Upadhyay, R.C. 2003. RAPD markers assisted selection of genetically diverse parents for hybridization in Agaricus 
bisporus. Mush. Res., 12(1): 19-26.

Yadav, M.K., Chandra, Ram and Dhakad, P. K. 2016. Biodiversity of edible mushrooms in Vindhya forest of northern India. Indian J. Agrl. Sci., 86(8): 1070-5.

Yin, Y., Liu, Y., Huamin, L., Zhao, S., Wang,
S., Liu, Y., Wu, D. and Xu, F. 2013. Genetic Diversity of Pleurotus pulmonarius revealed by RAPD, ISSR, and SRAP Finger printing. Curr. Microbiol., 1-7.

\section{How to cite this article:}

Yadav, M.K., Ram Chandra, H.B. Singh, S.K. Yadav, S.K. Yadav, Sushreeta Naik and Dhakad, P.K. 2017. Genetic Diversity Characterization of Pleurotus strains by Random Amplified Polymorphic DNA Fingerprinting. Int.J.Curr.Microbiol.App.Sci. 6(5): 1260-1267. doi: https://doi.org/10.20546/ijcmas.2017.605.136 